\title{
Differences over Difference: Sino-Russian Friendship at Interstate and Interpersonal Scales
}

\author{
ED PULFORD
}

\section{University of Manchester, Manchester, UK}

\section{INTRODUCTION}

The football match was advertised by something more like a policy document than a flyer. "Sino-Russian affection is deep" (ZhongE qing shen) it proclaimed as it circulated on social media platform Wechat, before explaining the aims of the contest. Held in the China-Russia border town of Hunchun between one team of Russian students and another of local Chinese government workers, the game would, we learned, "deepen Sino-Russian Friendship" and "promote government-organized communication between peoples" (cujin zhengfu zuzhi minjian jiaoliu). Under date, time, and location information appeared names of the organizing parties, among them Hunchun Municipal Communist Party Committee External Propaganda Center and the local government bureau for dealing with foreigners in Hunchun. A list of rules told us good behavior was expected of spectators and players: "This is a civilized match with scientific refereeing," it asserted. "Friendship comes first, the result comes second."

While speaking of the importance of "friendly" atmospherics to relations between China, Russia and other (post)socialist places, this presentation of a local sports match - one of many contests, song and dance shows, symposia, and artistic festivals held regularly in Hunchun under an aegis of official Sino-Russian Friendship - also made claims which seemed discordant, both to some players and to an observing researcher. On the day of the game, I asked my friend Alesha, who was on the Russian team, whether he thought it would achieve its goals. "This isn't friendship," he grimaced. "Look at all this ceremonial nonsense going on." He gestured at a bilingual pitch-side red banner that repeated the Friendship slogans from Wechat in large yellow characters. Since day-to-day Sino-Russian relationships are negotiated in Hunchun in an atmosphere of official cross-border friendship, such comments are common. Russian objections to staged Chinese-backed events 
as notional settings for cultivating "deep" ties are only one index of wider divergences between each side's approaches to forging interpersonal friendships.

The other, related, point of discord emerged when contemplating the event in the context of international relationships at large. The ability of state authorities anywhere to foster friendly organic bonds between populations often appears limited, and certainly more so than the inverse. Whipping up nationalistic antipathy of one people against another is a more usual way of buttressing a political agenda, and nationalism today a more revealing lens than internationalism for understanding relationships between governments, their citizens, and those of other countries. From the USSR and Yugoslavia to Scotland, Catalonia, and Brexit Britain, evidence of ordinary people rejecting friendships celebrated between their polities abound in both the Cold War era's former "camps."

Yet in places like China and Russia-countries bound by an official Friendship Treaty, no less - explicit invocation of friendship among people as part of positive relations among states remains a cornerstone of foreign engagements. For China, the extent of this is truly global: two 2013 speeches at which President Xi Jinping launched the PRC's flagship Belt and Road Initiative in Kazakhstan and Indonesia were respectively entitled "Promote People-to-People Friendship and Create a Better Future"1 and occurred alongside an exhibition of Sino-Indonesian Friendship. ${ }^{2}$ As the football match showed, however, such "big-F" Friendship projects pose particular questions in situations where, in addition to the official tie, significant numbers of citizens encounter and possibly befriend counterparts from a friendly state. To what extent is an interstate Friendship compatible with ordinary people's likely divergent understandings of the relationship in daily life? How do relationships unfolding among states influence those among people, and vice-versa? Northeastern Chinese border towns like Hunchun, where Russians are a constant presence, offer a chance to address such questions.

This article takes the Sino-Russian case as a starting point to interrogate the dual scales of interpersonal and interstate friendship, and the differing cultural conceptions of friendship, which emerge as initiatives like "government-organized communication between peoples" are negotiated on the ground. Investigating this demands an ethnographic focus on crossborder relations in Hunchun, and a historical one on the official SinoRussian/Soviet tie. Scholars seeking to reconcile interstate and interpersonal relationships from various perspectives, whether looking for the everyday in

\footnotetext{
${ }^{1}$ Xinhua 8 Sept. 2013, http://www.xinhuanet.com/politics/2013-09/08/c_117273079.htm (last accessed 10 Feb. 2021).

${ }_{2}^{2}$ China Daily, 4 Oct. 2013, https://usa.chinadaily.com.cn/china/2013-10/04/content_17008940. htm (last accessed 10 Feb. 2021).
} 
the international or the international in the everyday, have not thus far adequately accommodated both in the same frame, as I will show. Yet well beyond the Sino-Russian case, seeing how these relationships intersect is vital in an indeterminate age "after the post-Cold War" (Dai 2018), amid the relational friction (Tsing 2005) of myriad anthropogenic crises. This study of Friendship, just one of several anthropomorphizing euphemisms which clothe interstate ties - from partners to rivals, adversaries, enemies, and allies -argues that we see dynamics among persons and states in terms of overlaid "scales" rather than discrete "levels" of relationship.

As I elaborate below, a scalar approach reveals that bonds among states and among people from those states are simultaneous, mutually entangled, and operate around the same contours, rather than existing separately and independent of one another as the idea of "levels" suggests. Partly a product of academic disciplinary boundaries, and partly of global power divisions, positing separate "levels" of relationship implies that states are not run by people who are people in the same way as "we" are people, and thus that they must be understood differently. But border locales such as Hunchun show how state-state dynamics and everyday lives operate together. Consequently, neither should be taken as an a priori analytical frame for the other. This multiscalar study is also multi-perspectival, taking both Russian and Chinese relationship-making into account and revealing the asymmetries produced by their encounters. In an era when citizens and states alike must negotiate relations with people from other places, and as geopolitics and globalization reshape understandings of friendship itself, the anthropology of international relations and the politics of cross-cultural ones have both practical and analytical importance.

$$
* * * * *
$$

The football match concluded in a 4-1 drubbing for the Russians. It was observed by separate groups of supporters who, reflecting a wider lack of organic amity between Russian and Chinese residents of Hunchun, did not mix with one another, and the whistle blew for full time well before 90 minutes had elapsed. "Scientific refereeing" had been jettisoned to save face for the losing side. Afterward the two teams gathered for a photo with the Friendship banner, shook hands perfunctorily, and went their separate ways.

Conducting fieldwork in Hunchun over recent years, including a long stint from 2014-2015 and several visits since, I have attended many official Friendship events, from concerts to symposia, have read dozens of Chinese and Russian media reports of the new heights reached by official SinoRussian Friendship, ${ }^{3}$ and yet I have also encountered a wider field of

\footnotetext{
3 A good recent example is: People's Daily, 25 May 2020, http://world.people.com.cn/n1/2020/ 0525/c1002-31723139.html (last accessed 10 Feb. 2021).
} 
everyday frustrated friendlessness in the town itself (and a few successes). Helping to organize local cultural events, working as a translator, assisting in shops, and studying at a nearby university, with friendship as both subject of enquiry and research method, I have also felt caught in the midst of troublesome ties among Russian and Chinese interlocutors with divergent perspectives on relationships. As elaborated below, people of each group often voice disagreement over classic anthropological concerns such as the balance of formal/spontaneous and instrumental/affective elements of relationships. These may appear distinct from anything that would matter among states, but they ultimately coalesce into wider senses of Otherness which, in turn, allow us to reframe interpersonal and interstate relationships together.

Hunchun makes for a compelling site to demonstrate this and is in fact a friendly node for more than just the vast Chinese and Russian worlds. The town lies on the North Korean border too, and today's diverse municipal population of around 226,000 is 52 percent Han Chinese, 38 percent Korean Chinese (ethnically Korean PRC citizens known in Korean as Chosŏnjok) and 10 percent Manchu, ${ }^{4}$ with several hundred Russians present at any given time. This is thus a convergence of multiple populations whose relations have been officially "friendly," under socialist and postsocialist projects both within and among the PRC, Russia/the USSR, and North Korea.

The most totalizing of these projects, as keenly felt in its 1960s-1980s demise as in its 1950s heyday, was the official Friendship between China and the Soviet Union. The force of this relationship, its modified reemergence in a post-Soviet Sino-Russian form, and the unfeasibility of accounting for all possible ties in such a diverse location as Hunchun, account for my focus here on China/Russia relations. I will also concentrate primarily on Han Chinese and ethnically Russian citizens of each country.

The atmospherics of (post)socialist state projects are only one reason why friendship is important here, for the relationship also has a vernacular local salience. Borderland or migratory settings such as Hunchun form a kind of "frontier" social ecology (Hruschka 2010) where, as Igacio Martínez (2014: 321) notes, cross-cultural and multiethnic friendships may emerge to mediate hardships or get things done. Scholars working on China have observed that frontier population movements like those which Hunchun has witnessed for much of its history ${ }^{5}$ see family and lineage-based ties attenuate, making non-

\footnotetext{
4 Hunchunwang, 25 Mar. 2014, Hunchun renkou minzu, http://www.hunchunnet.com/archives/ 788/ (last accessed 10 Feb. 2021).

5 Trends of multiethnic in- and out-migration, whether from Russia, northern China, or northeastern Korea have been the norm here since the late-nineteenth century. Twentieth-century developments included the 1937 deportation of Korean and Chinese residents of the Soviet Far East, 1960s arrivals in Hunchun of Shanghai "sent down youths," and post-1990s departures of local Chosŏnjok to South Korea (Freeman 2011).
} 
kin relations emerge to the fore (Stafford 2000; Pasternak 1969). While lineage has different valences among Russians or Koreans, similar effects of detachment from pre-existing communities are a feature of most migrant biographies. All of this makes friendship a possible and indeed desirable relationship for local people beyond the pageantry official Sino-Russian Friendship, as I will now show.

\section{THE SEARCH FOR FRIENDSHIP}

Deeper frontier and statist histories will be important to my arguments, particularly as I compare socialist and postsocialist friendships, but contemporary Hunchun presents both an official Friendship and a crosscultural contact scenario which are of relatively recent vintage. Today's Sino-Russian Treaty of Good-Neighborliness, Friendship and Cooperation was signed in 2001 by Presidents Vladimir Putin and Jiang Zemin just as Russians were starting to come to Hunchun. Deng Xiaoping's "opening up" of China and post-Soviet loosening of border controls had permitted movement in both directions since the 1990s, and Hunchun joined earlier starters such as the towns of Suifenhe and Heihe as a popular cross-border destination around 2000. The thousands of Russian Far Easterners who now arrive annually comprise both longer-term settlers and people spending just a few days or weeks. Long-termers holding individual visas include pensioners, students (like the football players), teachers, and nightclub performers, while those on shorter visits come on group tour visas as shoppers (for household goods, clothes, toys, and auto parts, among other things), traders, leisure tourists, or medical patients (private Russian-oriented hospitals are numerous). However, even short-termers make repeat visits and roam Hunchun freely, their "tours" being largely nominal, and so regardless of length of stay extensive local familiarity and reiterative Sino-Russian relationships are common. Fieldwork put me into extensive contact with Russian and Chinese men and women of various backgrounds and durations of stay, and it is on their collective experiences that I draw. ${ }^{6}$

Visually, Hunchun bears many trophies of a rapid departure from carefully curated, socialist internationalism (when little cross-border contact occurred) to a new neoliberal internationalization. The town's appearance and demographics have been transformed by income from a post-1990s remittance economy driven by Chosŏnjok sojourning in South Korea and PRC government investment aiming to make this an infrastructural "hub for Northeast Asia" (as ubiquitous publicity posters declare). The local

\footnotetext{
${ }^{6}$ Consistent with frontier relationships, which have long been considered archetypally "male" (Tsing 2005: 27), relationships among exclusively female or male friends do exhibit distinct qualities in Hunchun. But my focus here is on broad patterns which applied to most local friendship situations, not only the most gendered extremes.
} 


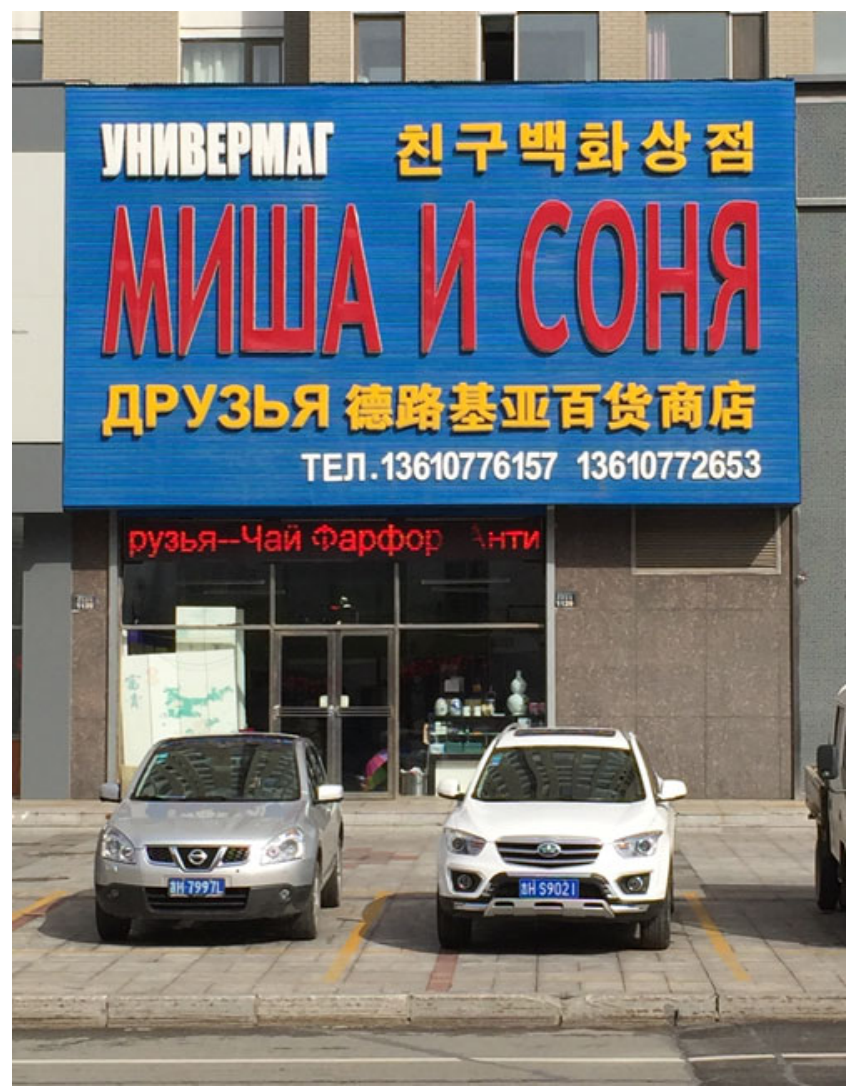

Image 1: Multilingual Hunchun shopfronts. The shop is called "Friends." Author's photo.

streetscape forms a dizzying patchwork of architectural and linguistic cyphers, from a mock-tsarist Post Office to traditional Chinese gardens, South Koreanstyle numbered apartment buildings, and shopfronts displaying a jumble of Chinese characters, Russian Cyrillic, Korean hangeul and, sometimes, Latin script English signs ( $\times$ image 1$)$. Trade and tourism, both domestic and crossborder, are among the primary local industries today, while the sclerotic remnants of older coal mining and forestry concerns rust on the margins. The Chosónjok outflux to Korea has been matched by Han in-migration from northern China. Contact here is thus facilitated by an interstate Friendship with socialist antecedents, but also unfolds in vernacular settings similar to many others globally over recent decades of post-Cold War mobility. These, in turn, lead to plentiful reflections from each side on the possibility for making friends in Hunchun. 
Liuba, a retiree whose biography resembled those of many older Russians in Hunchun, offered a common perspective on the potential for cross-cultural friendship. Having worked as a civil servant in her nearby hometown of Slavianka, she had arrived six years previously and bought an apartment with her husband. An active organizer of Friendship events, she noted during our conversations that life this side of the border had many benefits, from safety and affordability to a bustling and neat atmosphere quite different from dilapidated eastern Russia. But when speaking of relationships, Liuba was less positive. Despite the length of her residency and her involvement in cross-cultural affairs, she had few if any Chinese friends. "The issue is," she told me one summer day as we sat in a lakeside park, "that Chinese people want to be friends with you in exchange for something [za chto-to]. So, if someone is befriending you, it's clear they have something in mind. Maybe it's not necessarily monetary investment, but anyway it won't just be a straightforward relationship."

From the opposite point of view, Xiaoling, a twenty-nine-year-old Han Chinese vendor from a Hunchun business family who had arrived from Qiqihar in neighboring Heilongjiang province several years before, voiced an equally common perspective. She ran a shop in the compound surrounding Hunchun's China-Russia border crossing and this job, together with a father who imported Russian seafood and a sister who guided tours to Vladivostok, gave her many opportunities to meet Russians. But her failure to cement relationships had left her frustrated: "Why is it so hard to make a Russian friend [Eluosi pengyou]?" she lamented over coffee. "I've been trying for years. Even studying Russian at a training center didn't help." Xiaoling was motivated in part by the excitement of cross-cultural communication (jiaoliu) for its own sake, and this had sparked our friendship since she initially assumed I was Russian.

Significantly, she also shared her hope that friendship might facilitate starting a cross-border trading business. "But Russians seem so cold when I suggest this," she concluded. Xiaoling's day job in the border compound embodied the coterminous limits of her amical and commercial ties. Her shop sold "Russian goods" (Ehuo) to Chinese tourists, but in a common quirk of such emporia, all her Ehuo-matreshka dolls, vodka, chocolate, pleather wallets-were faux-Russian goods made in Heilongjiang. Despite being on the border and trading in the frisson of international connection, this was a node of exclusively Chinese flows.

Liuba and Xiaoling's experiences speak of how encounters often unfold in this setting doubly primed-by the frontier social ecology and constant invocation of Sino-Russian Friendship - for cross-cultural ties. Theirs and others' explicit, if fruitless, search for friends and friendship (pengyou/youyi in Chinese, drug/druzhba in Russian) sets places like Hunchun apart from settings where scholars have at times found the relationship as analytically 
slippery as these interlocutors found it practically elusive (Beer 1998). Indeed, early functionalist anthropological studies (Fortes 1953; Wolf 1966), and some sociologists (Pahl 2000), dismiss friendship's existence beyond societies (usually Euro-American ones) where the absence of lineage obligations frees an individual to pursue volitional, affective non-kin relationships. More recent work in anthropology (Desai and Killick 2013; Bell and Coleman 1999; Descharmes et al. 2011) and elsewhere (Berenskoetter 2007) has applied "friendship" as a flexible heuristic to interrogate various relationships not necessarily labeled "friendship," complementing capacious reappraisals of kinship (Carsten 2000). But in Hunchun today friendship's overt existence demands an approach which differs from both of these precursors. Active searches for youyi and druzhba here require both that we take it seriously in an at-most-only-partially "European" setting and that we see it as more than an externally applied heuristic. We need to account for how explicitly named friendships are understood and operate rather than fitting diverse relations into a "friendship" rubric.

By returning of friendship qua friendship into the analytical fold I do not intend to posit youyi and druzhba as analytically the same-indeed, this is part of my point. In their own practical and linguistic settings each sits within distinct, if overlapping semantic fields, with dictionary definitions suggesting youyi's association with more generically "friendly" interaction and druzhba's with greater levels of intimacy. Yet crucially, as well as being constantly discussed in daily life in Hunchun the two are a long-equated translational pair, occupying cognate spaces in Russian and Chinese social science, literature, and politics, of which treaty titles are only one expression. Much of this formal equivalence-drawing, I suggest, is itself a product of the long history of socialist internationalism and transference. I thus proceed here from the fact that the two are simultaneously anchored as equivalents within notionally reciprocal and equal (post)socialist state relations, and yet also operate differently in everyday life. Liuba, Xiaoling, and Alesha's frustrations all invite us to consider why everyday Sino-Russian encounters in Hunchun, despite in principle offering chances for a vernacular "translingual" (Liu 1995) rapprochement between youyi and druzhba, only rarely produce this. My proposal for how to make sense of this is a scalar one.

\section{SCALES：JUST A DIFFERENCE}

Drawn from the Hunchun ethnographic setting itself, a scalar approach allows us analytically to accommodate interpersonal and interstate relations together in a new way. Closer examination of everyday interactions here shows that Russian and Chinese counterparts diverge most in their readiness to make friends with someone seen as Other, and it is these differential approaches to difference-differences over difference-which indicate that interstate Friendship is a "scaled-up" version of the vernacular bond rather than an 
independently operating level of relationship. Among exclusively Chinese or Russian friends, practices of youyi and druzhba may involve varied approaches to difference of various kinds, but here in Hunchun the most pivotal contours of difference perceived by both sides lie categorically between Chinese and Russian counterparts. These generalized senses of Otherness which determine whether or not relationships work out are constructed in various ways discussed below. But their wider importance is already evident in Liuba and Xiaoling's own interactions. As Liuba reflected further on her encounters with apparently instrumental Chinese people: "Well, at the beginning it bothers you, but then later you realize that's just how it is here, it's just a difference [prosto raznitsa takaia]." "The Chinese," she continued, "have a different mentality [chuzhoi mentalitet]" around relationships. Her familiarity with this had seen her move from initial frustration, through understanding Chinese relationship practices as an immutable cultural difference, and finally to accepting this difference, notwithstanding its implications for her social life: no Chinese friends. Difference thus posed a potential barrier to relating.

Xiaoling's reference to prospective "Russian friends" was equally revealing. More coded than Liuba's outright invocation of fundamental Otherness, this nevertheless gestured at how difference is less of an impediment to Chinese friend-making: "Russian" may be not simply a modifier for "friend," but a characteristic of a kind of person whose Otherness is enfolded within feelings of friendship. But Russians on the receiving end of efforts to make them "Russian friends" have less tolerance for the idea that friendship be qualified in this categorical way.

As I demonstrate below, this shows that, notwithstanding extensive intercommunity familiarity in this frontier space, each side largely interacts with the other as Chinese or Russian people first and foremost. This makes the dynamics of everyday relations concurrently active on the state scale since differences running parallel to the Sino-Russian border have simultaneous vernacular and official significance.

The idea that interpersonal and interstate thus represent scales of the same kind of relationship builds on Biao Xiang's (2013) theorization of "multiscalar" ethnographic practice, and allows us to address blind spots within two existing strands of research into these relations. On one hand, International Relations scholarship has of late made room for growing interest in several "reflectivist" turns (Wehrer 2019), encompassing everyday International Relations, micropolitical, cultural (Callahan 2001), relational, feminist, nonstate, environmental, and social constructivist (Theys 2017) approaches, including in East Asia (Nordin and Smith 2018; Koschut and Oelsner 2014) and the former-USSR (Bukh 2020; Hopf 2002). Yet as noted by the editors of a recent special issue, there is little consensus on how to theorize "the 
everyday" within inter-polity relations, and state affairs remain a priority (Björkdahl, Hall, and Svensson 2019: 124).

From the opposite point of departure, state-focused anthropology has less difficulty conceiving of the everyday, how the "social life of the state" permeates intimate lived experience (Ssorin-Chaikov 2003; Humphrey 2004), or how the state itself operates socially (Scott 1998). But these studies rarely discuss everyday experiences of ties among states, even when interstate relations feature obliquely in work on borders (Reeves 2014; Simpson 2014), or in multi-sited (Marcus 1995) or "bifocal" (Inda and Rosaldo 2008) migration studies. Similarly eliding state-state concerns per se, research into intercultural friendships has generally been conducted within single settler-colonial settings (Reina 1959; Gudykunst 1985; Brandt 2013), or in cosmopolitan cities (Vincent, Neal, and Iqbal 2018).

Together, whether privileging the interstate and marginalizing the interpersonal or focusing on state effects without scrutinizing actually existing interstate relations, these approaches implicitly separate the two into disconnected levels (Wehrer 2019). Xiang's scalar paradigm allows us to bridge the gap. Based on research with a Beijing-based migrant community from China's Zhejiang province, Xiang primarily aims to offer an alternative to "multi-sited" approaches which would see Zhejiang hometowns/Beijing as different "sites," instead arguing that these must be understood as overlaid "emergent" and "taxonomical" scales of action and analysis. This approach shows how actions and events on the more hierarchical and bounded taxonomical scale, exemplified by state regulations to which Zhejiang migrants are subject in Beijing, also have a valence on the emergent scale as they play out in the migrants' hometown communities. Conversely, developments on the fuzzier, "actor-centric and activity-specific" emergent scale have taxonomical consequences as, for example, individual migrant business dealings carry simultaneous significance across the wider province and country.

Correspondingly in today's Hunchun, while on one hand state-scale postsocialist Friendship activates the downscale possibility for emergent friendships, those vernacular everyday relationships also have analytical value on the state scale. This is because of the importance of Sino-Russian difference to them. Xiang's disruption of the fixity of sites, and his argument that all events, actors, and interactions are "simultaneously located at a particular taxonomical scale and an emergent one" (2013: 285) is thus equally useful in dismantling the rigid "level"-based approach to interstate and interpersonal relationships. As interstate and interpersonal bonds interpenetrate one another, holding taxonomical and emergent in mind together reveals both the "institutional significance of ... daily life" (ibid.: 288) and its inverse. I now return to day-to-day friendship practices in Hunchun to show what they reveal about relations among states. Toward the 
end of the article, I then turn to reciprocal consideration of how interstate relations have simultaneous significance in everyday interactions.

MUTUAL ETHNOGRAPHIES

While Chinese and Russian interlocutors each see the other as Other, the possibility of befriending someone different is viewed asymmetrically. However, merely observing this is insufficient: as existing studies have shown, difference may be both an impediment to relating (Balibar 2005) and inherent to certain forms of sociality (Stasch 2009), and so there is a need to understand ethnographically how it is constructed in specific settings. With Hunchun exemplifying a little-considered scenario wherein people with different perspectives on difference interact, I will now show how senses of generalized difference emerge on each side.

Depending on the context of an encounter, Hunchun interlocutors discern difference in a variety of ways. While Liuba and Xiaoling diverged over instrumental versus affective concerns, the football match exposed issues around formality and spontaneity. I will treat these in turn, examining more closely Chinese and Russian counterparts' ethnographies of one another, before showing how specific relationship-making patterns are enfolded within wider "cultural" differences perceived by each side. Russian perceptions of excessive Chinese formality around friendship, or Chinese complaints of unpredictable Russian spontaneity, ultimately reflect only individual strands within wider bundles of perceived Otherness which may or may not be accommodated within friendships. Emergent relations are thus negotiated around taxonomical-scale difference between cultures (Russian kul'tura, Chinese wenhua), mentalities (mentalitet, sixiang), and customs (obychai, xisu).

The dissectional approach taken to show this may appear a somewhat bloodless denial of the processual elements of everyday relationship-making. However, this again is justified by the ethnographic setting which demonstrates precisely that each side interacts with the other through reified notions of culture rather than, for example, as fellow frontierspeople. In general, this allows little opportunity for more durative, processual patterns of relating to get off the ground, something immediately apparent in the field of instrument and affect.

\section{Instrument/Affect}

In a commerce-driven town like Hunchun it is unsurprising that transactional concerns and their balance with affective components of possible friendships are important. Like other frontier settings, this bustling postsocialist entrepôt sees a notable proportion of Sino-Russian contact unfold in vending or trade contexts. Yet, since this occurs as part of a wider field of reiterative interaction, relational dynamics go beyond the "business friendships" that 
have attracted scholarly attention amid growing Chinese involvement in international economies (Kriz and Keating 2010). They also unfold in a complex environment where Russians coming from a less economically buoyant location nevertheless do so as consumers, something whose implications I examine below when considering how taxonomical state-scale affairs manifest in everyday relations.

Many Russians echo Liuba's views that transactionalism has no place in friendship. Sergei, a forty-five-year-old cross-border trader had spent a decade in Hunchun undertaking various local business ventures, including export-import arrangements of the kind Xiaoling sought. "But I don't want to mix business and friendship," he said, "because then if the business deteriorates your friendship is also spoilt." Friendship was non-instrumental, Sergei explained, and he had often felt uncomfortable with how Chinese people seemed to take their relationship only so far before seeking to extract material benefit.

Many Chinese interlocutors were reciprocally sensitive to the effects of this Russian desire to separate affective friendship from instrumentality, including the owners of local shops where I spent time observing interactions between Chinese owners and Russian customers. Discussing these exchanges in his electronics store, Jiaxiang was one of many who hoped that his repeat interactions with clients would allow him to make "Russian friends." But mostly he was left bemoaning their mercenary shopping practices.

"Russians are obsessed with haggling [kanjia]," he said. "It's lihai," he added, using a term meaning "sharp"/“formidable"; e'ren - "extortionate"is another common epithet. "They'll come into the shop without saying hello, go for the lowest price and just leave if unsatisfied." Even long-term customers, I heard, with whom a relationship seems well-established, may simply disappear forever if something seems too expensive. Arguing mercilessly about price is seen by Russians as a legitimate pursuit in a transactional sphere ill-suited to friend-making (Stern 2015). But such sentiment-free practices are jarring to Chinese counterparts who contrast them with ideal-type exchanges involving polite inspection of items and gentler bargaining to cultivate affective bonds. Unlike for Russians, business need not exclude friendship, and indeed is better with it.

That both sides thus complain of the other's utilitarianism but in different contexts-Russians when looking for purely affective ties, Chinese people when seeking a mix - accords with how each group's relational practices have been seen in social scientific literature. As Oleg Kharkhordin and Anna Kovaleva (2009: 58-59) note, Russian men and women of various ages are given to see real friendship as an arena of pure feeling, one in which raw, spontaneous affect is generated through free emotional communication (obshchenie) (also Shlapentokh 1984: 215). Such intersubjective communion 
is, these sociologists conclude, polluted by instrumental concerns. Conversely, anthropological work on Chinese friendships has noted that "unquestionably deeply affective" ties may also "have decidedly instrumental features" (Strickland 2010: 103; also Huang 2008: 7), something Xiaoling and Jiaxiang were open to. In examining Chinese relationships based simultaneously on "mutual interest and benefit" and the cultivation of "feelings" (ganqing), studies by Mayfair Yang (1994: 1) and others (Kipnis 1997; Ledeneva 2008) have critically enriched anthropological understandings of global friendships, gifting, and economic morality. Such insights are also of further relevance here, for it is within the wider sphere of ritualistic yet affective interactions-which, as Yang notes, includes banqueting and other ceremonial occasions - that another bone of SinoRussian contention arises.

\section{Formality/Spontaneity}

Alesha, a thirty-one-year-old student from Kraskino (Hunchun's nearest Russian neighbor), had voiced skepticism at the football match about making friends in choreographed settings, and would often reflect on his wider relational struggles. Making Chinese acquaintances (znakomye) was easy, he said, but finding real friends was almost impossible since Chinese people merely "used" their "Russian friends," parading them in front of their compatriots at tedious dinners or performances to "show off." This complaint combined Russian objections to perceived transactionalism and to the environments in which friendship might emerge. Official Friendship events themselves brought these into particular focus, as even when finding them enjoyable on some level, Russians set little store by formal meals, concerts, or sports matches as fora for friendship.

Conversely, Chinese attendees valued these occasions as chances to cultivate affective bonds and mix with and befriend Russians in a convivial atmosphere. On the sidelines of one variety show, a businessman in his forties named Zhihao captured this with the following ditty about Hunchun:

It's a small town, not big,
The scenery is like a painting, 风城不大
The population is not large,
Everyone is good at drinking.

Zhihao's association of Hunchun's pleasant atmosphere with its Friendship festivities attested to a wider sense that these were chances for developing inclusively intimate relationships befitting this "small town." Yet he had also observed a certain Russian reluctance to reciprocate, and when I probed him admitted to not having actually made many friends in such contexts. Pondering why this was, he reflected that differential approaches to (in) formality were indeed a complicating factor. "They're so open and love 
chatting and dancing," Zhihao said, "these habits ... it's hard to get used to the cultural divide [wenhua chayi]." A kind of openness (kaifang) and rebellious attitude towards formality, he felt, left him feeling ill-matched to such displays of boldness and made it difficult to discern how interested Russians, whom he saw and spoke to most days, were in friendship.

Broader anthropological work in quite different settings shows how formality and spontaneity may each frame different kinds of tie. Harry Walker (2013) examines dichotomies between the joyful "play" of traditional sociality and the more rule- and role-based orderly association of soccer matches for the Urarina in Peru, and argues that soccer matches see Urarina adopt several newly ascribed categories of relationship associated with statehood and individual citizenship. At formal events in Hunchun, Russians are invited to enter a comparable sphere of categorical relating by inhabiting the role of "Russian friends," but most are reluctant to do so. Unlike the Urarina, who see a certain accommodation of new "modern," taxonomical relations as desirable, Russians are immediately braced against such classificatory formality since it is incompatible with the friendship they are being invited into. We will see that Walker's arguments may further help us assess whether everyday Chinese and Russian friend-making patterns align with wider state projects.

\section{Ideals and Practice}

Daily interactions in Hunchun thus see Russians advocating friendship based on spontaneity and affect, and Chinese residents more open to combining instrument, formality, and feeling. As an outsider to both social worlds, I did recognize each side's broad diagnoses of their troubles during my own interactions, both here and extending back to years living in China and Russia. Conversations with local Chinese interlocutors, from shopkeepers to my host family, would cover all manner of topics from global affairs to marital troubles and health. But with striking regularity, discussion would turn to how our friendship would be a good basis for selling something in the Western world I was seen to embody. Conversely, Russian friendships entailed high expectations of affective commitment and I found, for example, that any flaky last-minute change of plan from me would generate a larger cloud of sarcasm about being a "great friend" than I was used to in the UK. My own friend-making thus sometimes seemed to hover in the inbetween, since I felt too circumspect about diving into quixotic marketing schemes to blend in with Chinese friends, and too flighty and insincere to live up to Russian demands.

Such broad divergences, as already suggested, resemble the ideal-types documented in more culturalist analyses, yet even as my own experiences suggested that neither side's day-to-day relationships-either within or between groups-hove uniformly to the above-mentioned patterns, I found 
they were constantly invoked as people reflected on their social lives in Hunchun. Mutual ethnographies saw Russians echoing early functionalist privileging of sentimentality and choice in friendship, while Chinese perspectives more closely resembled recent anthropological openness to formality and instrumentality in the tie. Russian idealizations were no more idealizing than Chinese ones, but as different lines separating friendship from other things were drawn, the fact that Russian views matched those of early anthropologists may be unsurprising if we consider their common broadly "European" outlook, one incidentally also shared by Soviet propagandists during the Cold War (image 2).

While it is beyond my scope here to discuss, for example, "polluted" Russian friendships that do involve business or Chinese ones that deliberately exclude it, important questions remain about why the idealizations documented here play such a prominent role in Hunchun. In cross-cultural interactions, what might normally appear to be culturalist analytical views of friendship float to the surface as intimate, personal concerns: in anthropological terms, it is as though the "etic" interpretive framework of an outsider seeps into each side's internal, "emic" social practice. This means that rather than translingual rapprochement between youyi and druzhba occurring on the frontier, differences between idealized visions of each relationship continue to play a determinant role. The idealization thus becomes the process.

To understand this better, I suggest, we may examine the wider bundles of perceived static cultural difference in which relational elements such as instrument/affect and formality/spontaneity are seen to be embedded. Grasping how each side is in fact negotiating relationships around perceptions of more generalized Otherness will allow us then to recontextualize interstate Friendship.

\section{THE EXOTIC OTHER}

The conceptions of difference around which everyday friend-making pivots amount to often-racializing Orientalist and Occidentalist visions of static Otherness, whose exoticism is striking given constant mutual contact. This tendency likely owes something to an inheritance, on both sides, of "vernacular" (post)socialist social science (Kruglova 2017), which determines that every "people" possesses a particular mentality and customs. Thus, identification of one's counterpart and their behavior as "Russian" or "Chinese" over-determines encounters that might otherwise be more heterodox. As in Mei Zhan's ethnography of Shanghai international students studying traditional Chinese medicine, each side is attuned to the generalized differences that distinguish their encounters with the "other world": while Zhan's interlocutors are skeptical of things which seem insufficiently "Chinese" to be Chinese medicine (even if they are) (2009: 130), Chinese 


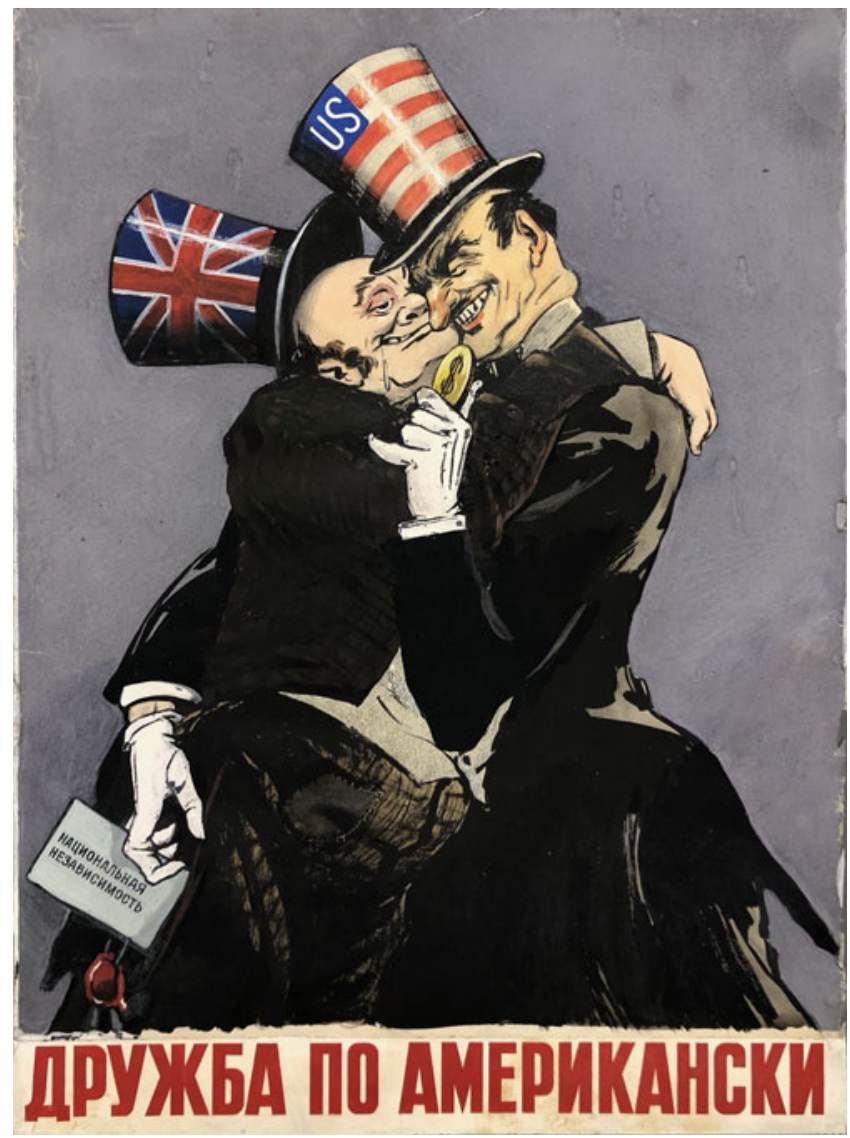

Image 2: "American-Style Friendship," Veniamin Markovich Briskin, Moscow 1954. The (probably antisemitic) portrayal of the American "friend" shows him buying "national independence" (the words on the letter). The transactionalism and unfreedom of capitalist relationships is thus contrasted with notionally purer, bounded, Soviet socialist bonds. From the Sergo Grigorian Collection, with permission.

and Russian counterparts, despite interacting in countless day-to-day settings, channel their relationships through categorical frameworks of difference that they then match up with idealizations of friendship. This gives Sino-Russian friendship patterns their multiscalar utility, for like the everyday business dealings of Biao Xiang's interlocutors unfolding in intimate hometown settings, the dynamics of these relations are simultaneously "national in scope," with resonances on the taxonomical state scale (Xiang 2013: 288).

Russian evaluations of generalized Chinese difference are sometimes guardedly positive in tone, since China is seen as a stimulating and alluring 


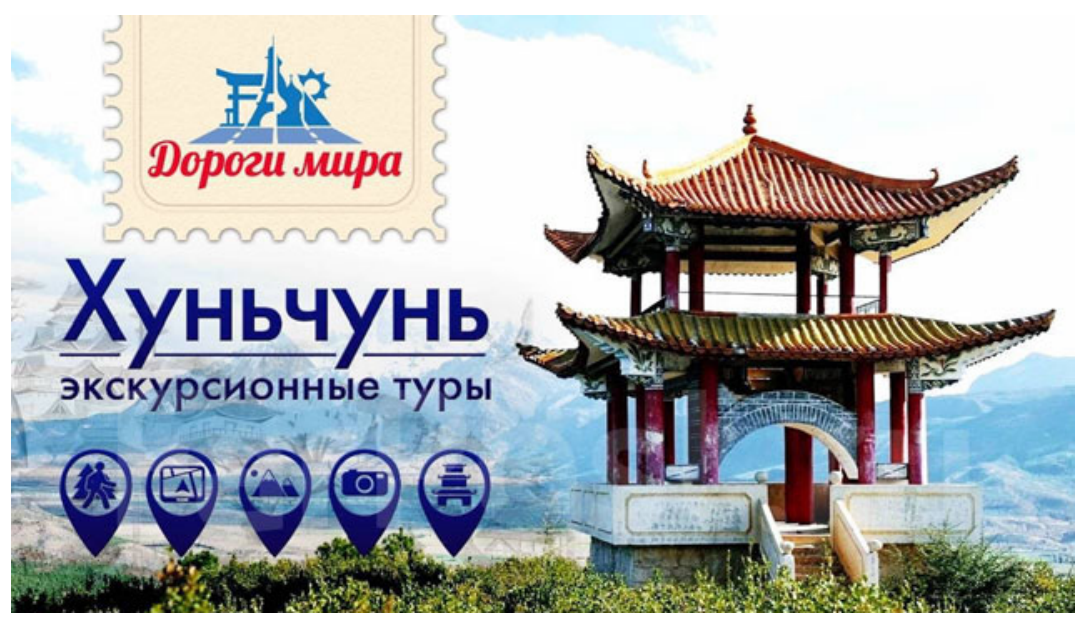

ImAGE 3: Poster for Roads of the World tour company featuring exotic pagoda. Retrieved from dorogi-mira.ru.

destination. The small Russian tour firms, which have just two or three staff and bring shorter-term visitors across the border, attest to this, boasting names that depict the modest distances they cover between decidedly provincial locations as leaps between worlds: "World of Travels" (Mir Puteshchestvii) or "Roads of the World" (Dorogi Mira) (×image 3). Racializing, negative attitudes are also present, and aside from condemnations of "cunning" Chinese instrumentalism, Russians who own apartments say they never lease one to Chinese tenants because "you'll never get it clean again." But with or without value judgements, attributions of Otherness to "the Chinese" or generic "Asians" are accompanied by statements invoking "just a difference," "alien mentality," or that "that's the culture."

Reciprocal Chinese views of the neighboring maozi ("hairies," an unflattering northeastern term for Russians) or zhandou minzu ("combative people," an irony-tinged label invoking purported Russian pugilism and stubbornness) similarly frame direct neighbors as distant and exotic. If the Chinese are "Asian" to Russians, then Russia's essentialization as "Europe" is most evident in Hunchun's main nighttime entertainment spot, "Europestyle Street" (Oushi jie). Built in the mid-2000s, the street forms a confounding parade of lurid Disneyesque buildings with turrets and cornicing, plaster models of Brussels landmark Mannekin Pis atop Corinthian columns, and bars named "Beerlin" (sic) and "Petersburg." Mirroring Russian tour company names, advertisements for Chinese tours to Russia blur generic views of "European" buildings (image 4). Chinese discussions of how many Russians live in Hunchun invert the numerical 


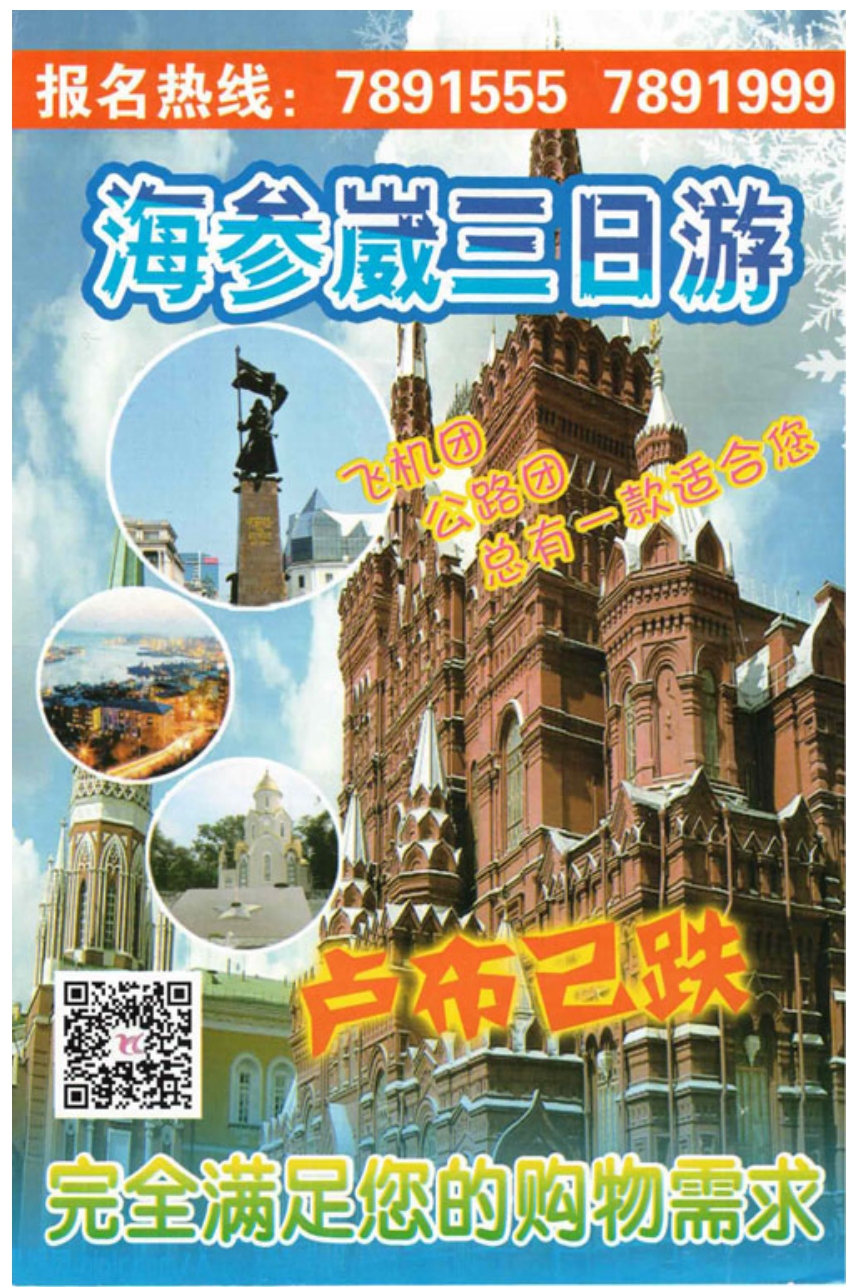

Image 4: Poster for Vladivostok tour displaying the Moscow History Museum, 4,000 miles away. Flyer handed out on streets of Hunchun.

inflation of racializing "yellow peril" discourses (Larin 1995), evoking masses of inscrutable Others. The two hundred some Russians in Hunchun form a small if visible proportion of the population, but Chinese talk of thousands of Russian residents with dozens of children in local schools is ubiquitous. (I was able to discover five children, at most.)

Yet differences over these symmetrically projected visions of difference are key to friendships. Tellingly, even Russians who, unlike Liuba, see themselves as having successfully befriended Chinese people nevertheless 
share her perception of immovable Chinese Otherness. Vova, the football team captain and a long-term Hunchun-resident in his thirties, considered himself a master of friend-making and would regale me with evidence of his "cultural" adaptations: "The Chinese never change, so you have to do what they do," he said, illustrating his point with a story about meeting a local official. "The man was sitting at his desk and I handed him some sweets. Then I saw in the cabinet behind him he already had the same sweets! But he still thanked me and ate mine." This, Vova observed, showed the importance of ceremony in Chinese friendship. "But," he added, "although lots of Russians know you should do this and develop 'feelings' [he used the Chinese word ganqing], few bother."

Other Russians with Chinese friends similarly described the need for cultural metamorphosis or smekalka, a uniquely Russian flexibility in challenging situations. I frequently heard the proverbial equivalent to "when in Rome...," namely "do not enter another's monastery with your own charter." Although Liuba, Vova and others described opposite outcomes, they shared a view of Otherness as a potential obstacle to friendship which, whether it can be overcome or not, must always be reckoned with. Rather than creating new, hybrid spaces between druzhba and youyi, Russians uphold boundaries, but may at times vault them into a distinct Chinese cultural realm.

Chinese transformation in the opposite direction was not unheard of, and some I met had indeed developed a taste for the spontaneous Russian "singing and dancing" referenced by Zhihao. But more often Chinese friendships in Hunchun showed that difference need not be such a barrier and indeed-as with "Russian friends"-it may be an intrinsic component of affective friendships. Ascription of the label "Russian" reflects a maintenance of explicit status positions in Chinese relationships of a kind noted by numerous scholars. Notwithstanding the recently documented "individualization" in PRC society (Yan 2009), relationship-making has been shown to involve reproduction of categorical ties such as "classmate," "colleague," or "fellow villager" rather than of a unitary subject (Smart 1999; Kipnis 1997: 36-37). As Xiaowei Zang notes in a comparison of Han Chinese and Hui Muslim friendships, the former often make friends around "status blocks or cultural boundaries" while still valuing individual choice (2003: 65). Even relational dyads which, like Chinese/Russian, imply status differentiation still encode a balance of reciprocal ganqing. Degrees of familiarity or expected commitment of course differ between peers (e.g., classmate/classmate) and non-peers (guest/host), but in Hunchun it is evident that, as between guest and host, from a Chinese perspective friendship with a foreigner whose foreignness is integral to the friendship need not be a qualitatively different, affect-free tie. 
Russians, though, have seen minimizing difference, such as that represented by formal or transactional tendencies, as key for druzhba (Kharkhordin and Kovaleva 2009: 74-75), achieved through abovementioned obshchenie, which overcomes boundaries of difference as "everyone's personhood [is] dialogized to produce a common intersubjective sociality" (Yurchak 2006: 148). ${ }^{7}$ Russians therefore balk at being a "Russian friend" precisely because the term encodes a category distinction incompatible with intersubjective communion. Thus even as, or rather partly because, Chinese intentions to make friends are translated into Russian at formal Friendship events, little vernacular mediation with youyi occurs and processual approaches are thwarted in their infancy.

Although I wish to avoid origin-seeking or determinism, these patterns might be seen as explicable given wider traits of the two "worlds" (per Mei Zhan or the bus companies) that converge in Hunchun. For one thing, Chinese and Russian societies are institutionalized to differing extents, and so Russian friendship based on deep trust and dissolved difference may befit an environment rich in cultures of informality (Ledeneva 2006) and lacking more reliable Chinese-style relationship-anchoring mechanisms, from government to lineages. Mutual contact may also help us understand China and Russia's places within anthropological debates over reciprocity, economic morality, conditionality of relationships, and the place of the sacred. Encounters here appear to bring one group who put work into separating "pure" gifts from commodities (Gregory 1982; Laidlaw 2000), and correspondingly sacred unconditional relationships from transactional economic ones, together with a second group whose reciprocity is rooted in an elaborate, if no less sacred, register of entangled gift-based and emotional exchange (Yang 1994). As Yunxiang Yan has noted, even in postsocialist northeast China, where "Confucian" and kin-based sociality patterns have diminished amid recent political and social upheaval, even relatively informal postsocialist relationship-making-for example seeking "back doors" into new social networks-still involves a blend of ethical and instrumental concerns (2003: 39-40).

Yet even if Hunchun offers each side ample chances to observe the other's relative interest in material exchange, formality, emotional expression, and spontaneous openness, actually making other-worldly friendships and thus shifting the parameters of the sacred within youyi and druzhba proves difficult. Having accounted for this, we are now equipped with an analytical frame to reappraise Friendship among states. State-scale youyi and druzhba are, as noted, anchored as translationally equivalent. Yet everyday Sino-

\footnotetext{
7 Eliding difference may be common to "European" relationships: see Brandt (2013: 245-56) on "similarity" among Pākehā and Māori New Zealanders.
} 
Russian interactions, whether at Friendship events, in shops, or elsewhere, continue to stumble over several overlaid contours of differentiation-among trade partners, notional hosts/guests, or cultural Others - all broadly coextensive with the interstate border. Emergent relational dynamics thus activate contours of difference which apply at the taxonomical scale, and knowing what these are we can now scale up our analysis to study state relations anthropologically. Categorical difference, it turns out, is of pivotal practical and analytical importance here too.

\section{( POST)SOCIALIST STATE FRIENDSHIP}

To see how the dynamics of interpersonal relationships operate among states, it is first useful to explore further how postsocialist friendship compares to that under high socialism. This is a complex picture involving both divergences and important continuities.

As already noted, conception of the Sino-Russian relationship as a Friendship owes much to its forceful promotion as the official bond both between China and the USSR, and among multiethnic populations within PRC and Soviet borders. Application of friendship in socialist international relations grew out of 1930s use of "Friendship of Peoples" (Druzhba narodov) to describe ties between the USSR's many ethnic groups (Martin 2001: 270). Following the October 1949 establishment of the PRC, and after several decades of more-than-friendly engagement with Soviet socialism among Chinese revolutionaries (McGuire 2017), a Sino-Soviet Treaty of Friendship, Alliance and Mutual Assistance was signed during a 1949-50 visit to Moscow by Mao Zedong. Five years later, the alliance between the USSR and the seven European Warsaw Pact states was instantiated by a Friendship treaty whose Russian title differed by only one word from its East Asian antecedent. These Friendships were animated by cultural events, joint building projects (Friendship Bridges link China to Russia and other postsocialist neighbors including North Korea and Vietnam), and a massive transference of Soviet industrial, military, and political technologies to China during the 1950s (Kaple 1994) (image 5), when the Sino-Soviet Friendship Association also became the largest single mass organization in the PRC ( $\mathrm{Li}$ 2018: 36).

However, even during this crimson Sino-Soviet efflorescence-when both also sealed Friendship ties with North Korea-Hunchun remained, as it had been since its 1714 foundation as a Manchu-Qing garrison, a relative backwater. Whatever the formal unity and cross-border "euphoria" (Bulag 2003: 757) of PRC-USSR-DPRK Friendship, this quiet, mostly Korean county town saw at-most-modest and strictly regulated contact across the borders on its outskirts. Minimal movement between Hunchun and neighboring Russian Primorskii region made Sino-Soviet Friendship something borderlanders generally read about in newspapers or celebrated 


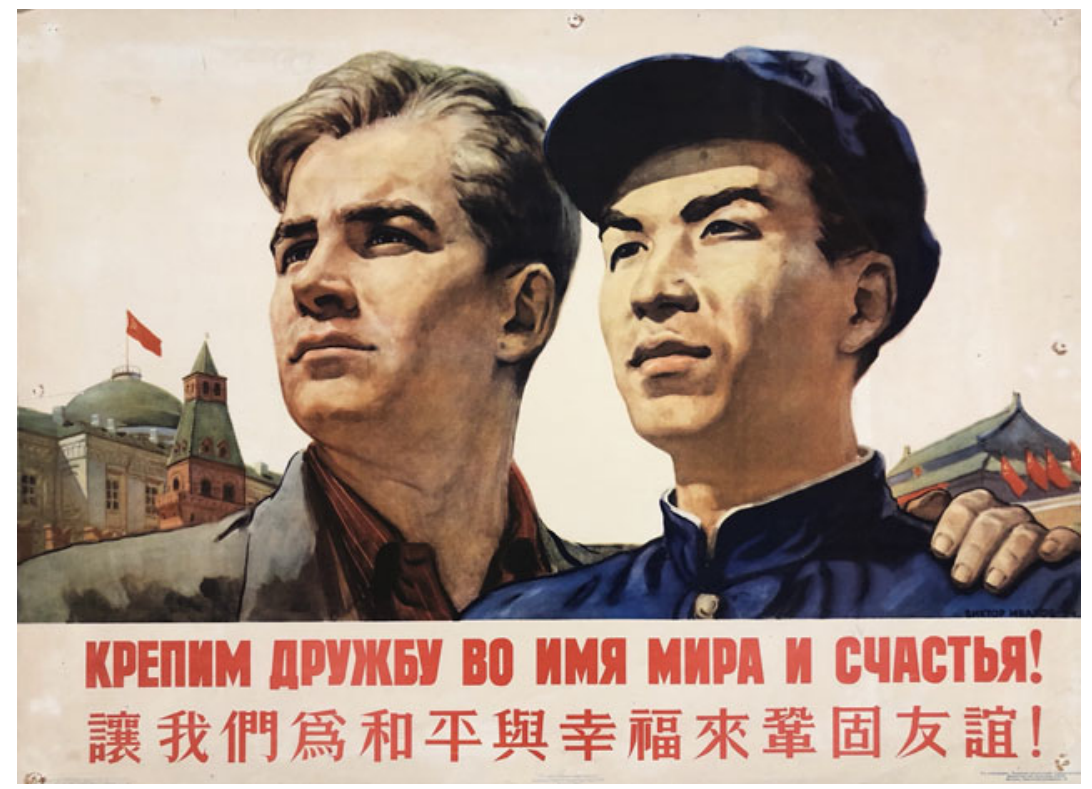

IMAGE 5: "We strengthen our friendship in the name of peace and happiness," in Russian and Chinese. From the Sergo Grigorian Collection, with permission.

with compatriots. Local Chosŏnjok with kin across the sluggish River Tumen in Korea were more habitual border-crossers, but even this dwindled as competing Kim and Mao cults strained PRC-DPRK relations from the 1960s. Occasional dance troupe or delegation visits were the sole, often literally choreographed expression of frontier amity with which a select few Hunchun attendees engaged.

Increasing fortification all along the 7,600 kilometer Sino-Soviet border during the 1950s (Urbansky 2012) made Sino-Soviet Friendship resemble cognate projects elsewhere. Similar controls on vernacular interaction existed among most Friendly states, leading scholars of socialist internationalism to question the very idea of Friendship: Soviet Friendship of Peoples (Hirsch 2005), Eastern European alliances (Applebaum 2019), Vietnamese (Bayly 2007) and North Korean (Young 2019) Friendships have all been seen as at best empty rhetoric and at worst cynical mobilization of fictive human warmth for imperialist purposes. Even when modest contact among citizens did occur, socialist governments are widely understood to have disliked their populations actually mixing with "foreigners" (Applebaum 2019; McGuire 2017: 287).

Understandably therefore, Yan Li argues that Sino-Soviet amity "had nothing at all to do with promoting personal relationships between the two 
peoples" (2018: 28), an argument which seems all the more credible given how quickly Friendship turned to enmity. The 1960s-1980s Sino-Soviet split was, as older Hunchun interlocutors on both sides attest, a period of near-total isolation from what was going on just over the Sino-Russian border ridge. Around a 1969 border conflict over Zhenbao/Damanskii Island, 500 kilometers to the north, the town was suffused with hostile propaganda declaiming the USSR's purported "revisionism" and "socialist imperialism"- -suspicions of which, as Austin Jersild (2014) notes, had been present even under high Friendship. While views on the ground of course varied, the transition to enmity may have been smoother for populations who - not really knowing one another-were more easily convinced that the nearby Other was now a foe.

For ordinary people in postsocialist Hunchun, therefore, continuities between Sino-Soviet Friendship and today's intercultural contact are confined largely to the realm of myth. Personal recollections of past crossborder dynamics as often feature the recriminations of the more recent split as they do wistful references to China's "Soviet older brother" (Sulian lao dage). Yet, importantly for our broader understanding of official Friendship, while the tie may have evaporated in the specifically 1960s Sino-Soviet case, neither side abandoned it as a mode of interstate relating. At local and national levels, Chinese and Soviet celebrations of Friendships with, for example, the Global South, endured beyond the split in ways still evident today. As in many spheres, China's post-Mao shift to a more marketized economy has not been accompanied by equivalent changes in the symbolism and institutions of state, and so almost all Beijing's significant international relationships remain suffused in Friendship, from African nations such as Tanzania and Angola to Pakistan, Europe, and Central Asia. In June 2018, Putin was awarded The Order of Friendship, the PRC's highest international honor, at a ceremony in which $\mathrm{Xi}$ described him as his "best and most intimate friend" (see image 6). ${ }^{8}$ Today's Russian Federation has more formal discontinuities with the USSR than the PRC does with its earlier selves, but, as in many other parts of the (post)socialist world, elements of the friendship-diplomatic complex remain intact here too. Russia, Kazakhstan, Uzbekistan, Cuba, and North Korea all have Friendship Associations to manage external relations and confer their own Friendship Medals on foreign dignitaries: like youyi and druzhba, dostyq, dustlik, amistad, and chinsŏn thus remain one another's formal Kazakh, Uzbek, Spanish, and Korean translations.

\footnotetext{
${ }^{8}$ Reuters, 8 June 2018, https://uk.reuters.com/article/uk-china-russia/chinas-xi-awards-bestfriend-putin-friendship-medal-promises-support-idUKKCN1J41RJ (last accessed 10 Feb. 2021).
} 


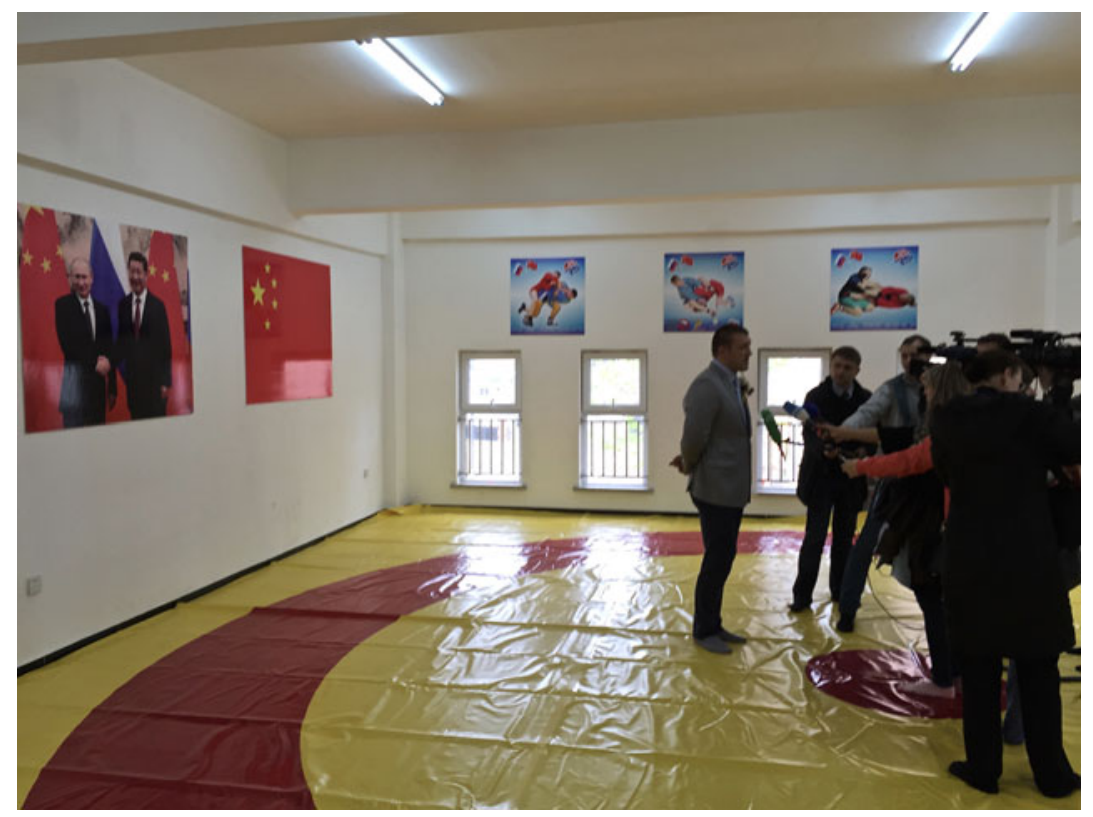

ImAGE 6: Xi Jinping and Vladimir Putin adorn a wall during a Day of Friendship to mark the opening of a new martial arts club in Hunchun, 2015. Author's photo.

Yet if this explains why socialist-style atmospherics clothe renewed postSoviet Sino-Russian relations, the fact that postsocialist Friendship now allows for everyday engagements among citizens in Hunchun is not wholly ignored in official messaging. Marking a post-split thaw in relations which began in the late 1980s, the 2001 Jiang-Putin Friendship Treaty includes an element absent in its Mao-Stalin predecessor, namely "good neighborliness" (Chinese mulin, Russian dobrososedstvo). The high formalism of earlier treaties cast states as disembodied entities floating in space, unencumbered by the physicality of frontier relations. But good neighborliness - also featuring in a China-Southeast Asia treaty mooted by Xi in 2013-reflects a new era of acknowledged contact and human mobility. Everyday interaction is indeed a core feature of twenty-first-century international Friendships as Chinese workers, technicians, and others ride Belt and Road vectors outward, and foreign students, traders, and migrants come to China and interact far from established networks. Having already discussed how such transnational interactions unfold in the Sino-Russian case, and the pivotal importance of difference to these, I will now reappraise the official tie in light of everyday friendship and show why the two may be out of step. The socialist-era ignoring of Sino-Russian neighboring is an entry-point here, for it reflects 
the importance of bounded categorical difference among discrete states as a tenet of interstate Friendship well before high socialism.

BORDERS OF DIFFERENCE

Everyday friendships in Hunchun see each side approach difference asymmetrically, but interstate Friendship, by virtue of its embeddedness in a hegemonic international political system, has a kind of forced symmetry. This is because states must, to use a geometrical metaphor, tessellate as spatially and administratively commensurate units. Categorical differences parallel to those that are pivotal in Hunchun must therefore notionally carry the same weight in, for example, Moscow and Beijing's approaches to druzhba and youyi. Considering interstate Friendship's deeper history sheds further light on this.

As political scientist Evgeny Roshchin (2009a: 126-32) shows, Russia's first eighteenth-century encounters with diplomatic Friendship came as growing interactions with European states saw Muscovite Tsars move from issuing "charters" (gramoty) unilaterally declaring "love" for recipient powers to reciprocal exchanges of treaties expressing druzhba. This was coterminous with a process whereby states themselves were being understood as bounded, post-Westphalian sovereign entities. Unlike love among fuzzy polities with blurred boundaries, such as old Muscovy, Friendship described relations between geographically discrete and qualitatively commensurate units, serving as "a defined guarantee for ... control over a unified territory, the defense of borders, and a guarantee of order" (Roshchin 2009b: 410). Friendship, statehood, and exclusive sovereignty thus became mutually constitutive since identifying another state as a friend entailed common submission to a legible regime of linear borders (see also Derrida 2005).

Shifting understandings of everyday relationships underlay this novel application of "friendship." European conceptions of what friendship is as a personal relationship have long changed in line with sociopolitical transformations (Grayling 2013), and the post-Enlightenment era of burgeoning Westphalian statehood was a time when, at least in intellectual circles, it was seen as a bond among bounded, self-possessing individuals (Kon 1987: 9). These ideas, I suggest, were thus reflexively mapped onto states at a time when new political entities and new types of statehood were being born from revolutions on both sides of the Atlantic. Indeed, the architects of the era's political transformations and the promoters of rugged personal amity were often the same (invariably) men. In Russia, intellectual architects of Peter the Great's reforms developed the idea of the agentive "self" (samost') (Kalugin 2009: 188, 280-81), while robust American republican individualist Ralph Waldo Emerson saw interpersonal friendship as "an alliance of two large, formidable natures" (1993: 47-48). 
Interstate Friendship thus had the culturally specific Euro-American idea of categorial differentiation among bounded entities at its core from the outset. Given their common conceptual inheritance, Westphalian polities and sentimental individual persons were framed as cognate bodies making sovereign decisions to engage in the bond. This, then, was the idealized vision which proliferated from the USSR, a Russian-inflected apotheosis of many of post-Enlightenment modernity's most categorical ideals and formal taxonomies. Twentieth-century socialist internationalism, with its repudiation of colonial border-transgression, ensured that the idea of friendship among agentive entities separated by linear contours of difference was inherited by the PRC, the DPRK, and other states which traced tangled threads of heredity back to European revolutionary republicanism (Skocpol 1979).

In this context, interstate Friendship's power may indeed have lain in its ability to overstep linear boundaries and forge a kind of pooled political subjectivity cognate with that which Russians seek in Hunchun today: the promise of socialist "internationalism" itself arguably rested on the idea that discrete actors had separately chosen to pursue a common cause. In practice, of course, a tongue-in-cheek reading of the Soviet government's willingness to intervene in the domestic affairs of its Eastern European Friends, and the fact that from Afghanistan to Angola it was only through extensive "help" that Moscow-friendly governments were installed over the twentieth century, might suggest more-than-expected compatibility with a Russian-derived openness to overstepping boundaries of difference. Yet categorical differences among "independent" states (per the Soviet poster in image 2) remained a vital conceptual totem.

Returning to consideration of China, the idea that socialist Friendship entailed the maintenance of formal difference notwithstanding indivisible unity raises curious questions. As a socialist state whose 1949 Communist revolution had come about only partially thanks to Soviet assistance, the PRC rested on cultural underpinnings in which friendship and relationality were understood very differently compared to in Europe or the Soviet Union (Yang 1993). Yet Sino-Soviet Friendship, like other bonds among revolutionary socialist states celebrating powerful separateness but also shared political objectives, may in fact have appeared more compatible with vernacular difference-retaining Chinese friendships theorized here. I return to the implications of this.

A scalar approach to the interface between interpersonal and interstate friendships thus shows how Hunchun's emergent ethnographic context helps us reappraise taxonomical ties among (post)socialist states. On both scales, I have shown, parallel contours of difference are pivotal, but while these are approached asymmetrically in everyday relationships, among states they must ideally be seen symmetrically. I now reverse the direction of analysis to show how the actual, and rather less ideal, operation of interstate dynamics 
has downscale consequences for everyday friendships too. Thus far I have dealt with idealization on both scales, but moving deeper into the practical realm reveals the messy ways in which multiscalar Sino-Russian friendships unfold in Hunchun today. This may offer both an explanation for why everyday friendship is not blossoming here and grounds for reappraising interstate and interpersonal more broadly.

\section{FRONTIER ANTAGONISTS}

Interstate dynamics have meaning at an everyday scale as rigid taxonomical affairs play out in Hunchun's looser emergent "frontier" context. Chinese and Russian people here resemble many frontierspeople across time in being both economically and administratively precarious and, to a significant extent, mutually reliant. Most Russians, including long-term residents, speak of feeling like priezzhie - "entrants" or "outsiders." Even those who own apartments or have regular employment in schools, trade companies, travel agencies, or nightclubs face bureaucratic vulnerabilities. Since PRC migration policies favor white-collar foreign "talents" (Bork-Hüffer and Yuan-Ihle 2014), entities employing Russians cannot sponsor long-term work or residency permits. Not for want of trying, therefore, most retain only "tourist" legal status. Life may be materially more comfortable here, and jobs, however contingent, are easier to find than amid the post-Soviet decay of small-town eastern Russia. But the sense of being priezzhie remains, alongside an implicit contrast to Chinese "locals."

Yet the Chinese people with whom most Russians interact are usually no more settled. Indeed, Hunchun's vendors or service workers are mostly wailairen - the precise outsider/entrant equivalent of Russian priezzhie - and comprise a shifting cohort of migrants from northeastern industrial towns which, like Xiaoling's home Qiqihar, have struggled economically in the post-Mao market era. Most thus come from further afield than Slavianka or Kraskino, and their mobility is as much a postsocialist phenomenon as Russian border-crossing is. Domestic migrants may encounter fewer bureaucratic hurdles, but differential urban/rural household registrations mean villagers moving to Hunchun (formally a "city") still face administrative complications. Seeking more comfortable lives just as their Russian counterparts do, these hard-pressed arrivals open shops like those I spent time in, or seek cross-border trade opportunities to zhengqian, an expression for "earning money" which implies saving up day-by-day. Russian custom and cooperation are vital to this, and so if these ventures fail people must try their luck elsewhere. The ever-changing patchwork of shops on Hunchun's streets are testament to wailairen precarity.

Yet parallel precarities and mutual exposure do not beget much relational reconciliation, even as they produce reciprocal familiarity like that also seen in African and Chinese domestic migrant encounters in Guangzhou (Lan 2019). 
One reason for this, I suggest, is to be found in the downscale effects of interstate Friendship dynamics. Even where one might assume unmediated and flexible "frontier" relations could develop, shifts at the state scale carry an everyday valence that may hinder emergent relationships.

Evidence of this emerged during 2014-2015, when a remarkable uptick in celebrations of official Sino-Russian Friendship was accompanied by a significant diminution of friendships on the ground. Warming of the interstate bond came as Russia's 2014 Crimean annexation and war in Ukraine coalesced with strained PRC-West relations, encouraging Moscow and Beijing to redouble affirmations of their Friendship. Presidents Putin and $\mathrm{Xi}$ met several times in 2014 and 2015, and, with Western leaders absent, each was a VIP guest at the other's World War II seventieth anniversary parade. Putin's 2018 award of China's Friendship Medal continued this trend. But beyond shifting Eurasian geopolitics, friendly Russian overtures to China also stemmed from insecurity caused by falling global oil prices, which had caused a drastic drop in the value of the ruble. Consequently, the same dynamics underlying deeper interstate Friendship meant that prices in Hunchun suddenly doubled for Russians, making life much less friendly.

Both blossoming interstate bonds and the currency shift played out across the contours of difference already discussed: mushrooming formal Friendship events left Russians more nonplussed than ever, while higher prices increased their resolve to get a bargain and sharpened suspicions of being ripped off by (apparently disingenuously) "friendly" Chinese vendors. Conversely, Chinese shopkeepers now confronted customers more insensitively averse to cultivating feelings in their dealings than ever.

These developments revealed the antagonisms of symmetrically dependent everyday relationships that were also exposed to distant and ungovernable state-scale shifts. Even in normal times, dynamics in Hunchun and other transnational trade hubs exhibit intensified traits of what Clifford Geertz called the "bazaar economy," in which vendors and clients are "at once coupled and opposed," mutually reliant but at odds in their goals (buying cheap/selling dear) (1978: 30-32). Like the "familiar" or even “intimate antagonists" of Geertz's Moroccan souq, parties to transactions in Hunchun are familiar partners in symmetrical demographic positions. But as shifting taxonomical dynamics change the terms of emergent interactions, degrees of both dependency and antagonism can be exacerbated to an unmanageable degree.

Biao Xiang shows how state interventions in the lives of Zhejiang migrants have simultaneous effects on provincial, county, and interpersonal scales. Similarly, the very state border which is constitutive of the whole idea of Sino-Russian Friendship in Hunchun also plays a pivotal role as a divider of economic spheres, and as a widener of differences between friendship practices. As well as intensifying already-problematic divergences 
over haggling, the currency crash reduced the number of Russians in town. Straining friendships in two countervailing but equally disruptive directions, therefore, this both forced Russia-reliant Chinese businesspeople to shut up shop and move on and yoked those who remained still closer into noncollaborative, mutually antagonistic relationships: fewer and more abrasive encounters further exposed each side's varying tolerance for the other's divergent cultural approaches to affect and exchange.

This twinning of blossoming official Friendship and its deteriorating interpersonal counterpart thus shows how actions across the same contours of difference at different scales may pull in opposing directions. This deduction leads me to conclude with a comparative appraisal of how we might see multiscalar friendships on a broader canvas, including in contrasting socialist and postsocialist cases. Offering Russian- and Chineselinked examples to illustrate this, I also suggest how interstate and interpersonal bonds might be approached in future research.

\section{COMPARISONS:FRIENDSHIP WITH OR AGAINST THE STATE}

\section{Soviet Friendship against the State}

As the precursor to later internationalist Friendships, Soviet Friendship of Peoples and interpersonal relationships under its aegis offer a productive contrast with today's postsocialist cross-border bonds. On one hand, Druzhba narodov shared some features of today's Sino-Russian dynamic, at once categorically separating mutually familiar populations via an elaborate system which ascribed "nationalities" with various reified differences (Hirsch 2005), and vaunting friendship between them. Indeed, the "Russian" football team in Hunchun included several representatives of the former-USSR's multiethnic population: five Russians, three Koreans, two Kazakhs, and one Ukrainian. However, unlike in Hunchun, there was often significant resonance between official and everyday friendships in Soviet contexts. Why this was can be reappraised here.

Russians and non-Russians alike found that official Friendship acquired everyday affective significance, notwithstanding the formality of festivals, concerts, contests, and exhibitions, which seemed to require that "all ... nationalities be deeply moved by the art of other Soviet nationalities" (Slezkine 1994: 447). In one Saint Petersburg-based study, culturologist Svetlana Lourié (2011: 145) observed that her multi-ethnic interlocutors identified a "common language, an understanding of the other" and "human warmth" in shared Friendship events. As Caroline Humphrey (2004: 146) notes, "real warmth flourished" precisely when, "After the parades, people partied all night, usually in a totally multi-ethnic ambiance. Audiences enjoyed the cultural achievements of other nationalities." 
To deduce what set Soviet citizens apart from today's Sino-Russian case, I suggest that, unlike for Hunchun's oppositionally "yoked" counterparts, the contours of difference distinguishing Soviet citizens at the state scale did not line up so neatly with potentially friendship-inhibiting differences in the everyday. For one thing, before the explosion of informality that has distinguished post-Soviet Russian experiences in most areas of society and politics (Ledeneva 2006), some Russians may have seen state-linked Friendship events as a firmer guarantor for some form of durable relationship. But more important, I think, is that the daily activities in which members of the USSR's multiethnic population were involved, while certainly not free from antagonism, did not so consistently pitch groups against one another, and encouraged certain forms of collaboration. Tellingly, this often ran directly contrary to state-scale activities, for it was as people waged struggles imposed by the socialist shortage economy that personal friendships arose. As Humphrey continues, "In everyday life, a great deal of comradeship also rested on a sense of shared hardship, common fears, and on the grey sameness of material life." Friendships offered access to scarce goods (Abrahams 1999) or a "refuge" from the unfriendly public domain (Shlapentokh 1984) where the "seller's market" meant "the seller [was] unfriendly and impolite with the buyer, while the buyer trie[d] to flatter the seller" (Kornai 1992: 248).

Interpersonal bonds based in part on conspiring to navigate bureaucratic tedium and material monotony thus had instrumental features that Russians in Hunchun today might shun. But with boundaries of difference inscribed in formal or transactional situations not being so consistently parallel with, for example, status differences between Russians and Kazakhs, people's vernacular ties were less neatly separated into realms of distinct friendship practice than Sino-Russian druzhba and youyi are today.

There was a rich irony in the fact that both Friendship and Cooperationtotems of Soviet state messaging equally ubiquitous in today's PRC flourished in vernacular form against the state. They were, in Alexei Yurchak's encapsulation, "very real humane values ... that the realities of socialism afforded - often in spite of the state's proclaimed goals" (2006: 8). This was underscored by the minimal official attention paid to interpersonal friendship, for while Friendship of Peoples appeared everywhere from street and university names to the Soviet national anthem, the only everyday bond that was really celebrated was Karl Marx and Friedrich Engels'. And even if paeans to this Great and Touching Friendship - in the words of one serially reissued book (Sukhotin and Vidgop 1958) translated into Chinese in 1983 (Weitegepu and Suhuojing 1983) - alluded to its deep affect, its strength was shown to lie in the men's characters as powerful independent minds united yet discrete, precisely the kind of intellectual tie on which the idea of interstate Friendship was based in the first place. For all its "touching" 
qualities, therefore, and while Engels' regular bailouts of Marx were eschewed, ${ }^{9}$ this was a metonym for taxonomical Friendship of Peoples and the USSR's Friendships with other socialist states.

Thus, while Soviet citizens belonged to discretely categorized peoples with culturally varied ideas about relationships, unlike today's Hunchun counterparts they faced similar state-imposed frontier struggles and forged intersubjective friendships across contours of difference in both formality and instrumentality suffused settings. Differential approaches to emergent relationships were less liable to be exacerbated by coalescence with structurally antagonistic taxonomical opposition and some translation between friendship practices became more viable.

\section{Chinese Friendship with the State}

Within China, too, a multiethnic population, differentiated under a classificatory system partly borrowed from the USSR during the 1950s, has been exhorted to forge mutual friendships while enduring common struggles and political excesses. But the analysis presented here also has implications for pragmatic questions around Chinese friendships beyond PRC borders over time.

While friendship and Chinese politics have long had an uneasy coexistence given the former's seditious egalitarianism against traditional preference for hierarchy (Kutcher 2000: 1616), Soviet-style mobilization of Friendship with the outside world began early in the PRC era. In the revolutionary 1940s, Han Communist cadres sought ritual friendships with neighboring Mongols (Bulag 2010: 115-17), while Chinese proletarians were exhorted to develop "class ganqing" with foreign counterparts (Kipnis 1997: 161-62). For a new state managing relationships in a potentially hostile world, friendship became a way of "treating outsiders differently" (Brady 2003): both whole countries and individual foreigners were classed as inimical or friendly to the CCP government, and until the 1980s foreigners invited to visit Beijing were lodged in the Friendship Hotel.

While the Sino-Russian case suggests that treating outsiders differently is incompatible with more boundary-dissolving visions of friendship, it may be that this kind of choreographed official youyi can be more easily reconciled with everyday relationships in a Chinese context. While Walker's Urarina interlocutors embarked on an unfamiliar trajectory toward taxonomical Peruvian citizenship by playing rule-based football, Chinese people's preexisting comfort with relating across difference may entail a greater readiness to befriend Russians as Russians than vice versa. To reiterate, this

\footnotetext{
${ }^{9}$ Mentioning the bailouts would ironically have strengthened the analogy: after decades of secrecy, a 1990 report revealed that of a total of 85 billion roubles of foreign debt owed to Moscow, two-thirds were owed by "friends," including Cuba and Vietnam (Friedman 2015: 219).
} 
is not to ignore a wide range of Chinese relationships across a spectrum of difference and encoding differential balances of affect and other concerns. But at least in a cross-border situation where youyi and druzhba are being explicitly negotiated the former has more scope for accommodating difference like that which separates states.

Beyond the present case, moreover, we may benefit from seeing emergent friendships between Chinese and non-Chinese counterparts elsewhere in terms of overlaid personal- and state-scale contours of difference. The same postCold War mobility underlying Hunchun's Sino-Russian contact has seen PRC citizens move throughout the world, and since work on the resulting day-to-day relationships generally sidelines state-related concerns, the present study offers a new paradigm. Intercultural communication scholar Yijia Huang (2008: 12-13) notes that differential accommodation of "culture" poses problems in potential friendships between U.S.-based Chinese students and their American counterparts, while reciprocal American objections to being "foreign friends" have been documented in China itself (Liu and Dervin 2020). Such work would benefit from consideration of the role that the SinoU.S. relationship plays in delineating how notions of "culture" are constructed on each side, all the more so at this time of growing trans-Pacific tension. In a different context, while activity at the state scale implicitly undergirds many relationships among Chinese and local co-workers in Zambia (Chang 2013), and generalized Sino-African interactions in Guangzhou (Lan 2019), work on these situations has not yet explored the bidirectional relationship between everyday ties and shifting official Sino-African Friendships. Janny Chang's (2013: 38) insights into how Chinese and Zambian colleagues forge relationships that appear to blend each side's approach to instrument and affect would be enriched further through a focus on how difference itself is managed, not least since these interactions occur at a PRC state-owned enterprise. With Sino-African relationships coming into focus recently amid racializing incidents during the COVID-19 pandemic, applying a scalar approach would shed new light on what happens when Chinese friendships with the state break down, as they once did during the Sino-Soviet split.

\section{CONCLUSION}

As cross-cultural relationships continue to multiply, the fact that Chinese "foreign" friends remain valid kinds of friend at different scales may pose provocative questions regarding global engagements involving the PRC, which still operates on a political system mostly inherited from a Friendly USSR. Could Soviet-style state socialism, with its relational classifications, interstate Friendship framework, and Xi Jinping's "people-to-people friendship" add up to a project better suited to a Chinese cultural backdropand to a new multipolar, bloc-based global order - than to the Russian and binary Cold War one from which it emerged? Whether or not people can 
forge foreign friendships compatible with state-scale arrangements depends, I suggest, on how they and their counterparts approach the contours of difference that separate them.

On a broader canvas, the present study presents questions for comparison with other global contexts. Beyond simply showing how international relationships play a part in people's lives, or how vernacular understandings of a given relationship influence its meaning among states, this study has privileged neither and thus reached a more balanced understanding of both. By discerning ethnographically the multi-scalar importance of senses of difference, and tracing the continuities and divergences between socialist and postsocialist friendships, I offer a general framework for examining how interpersonal and interstate relationships are entwined. Key questions to interrogate when applying this framework elsewhere include what role difference plays in each side's approach to a potential relationship, and to what extent the dynamics of the given state-state relationship exacerbates or minimizes senses of difference for each side. Addressing these may explain imbalances in one side's apparent feelings of friendship when compared to the other. As I have shown, these are important issues since even when people from different places "should" for sociological or political reasons be friends, today's world offers all-too-many instances in which they are not.

\section{REFERENCES}

Abrahams, R. 1999. Friends and Networks as Survival Strategies in North-East Europe. In S. Bell and S. Coleman, eds., The Anthropology of Friendship. Oxford: Berg, 155-68.

Applebaum, R. 2019. Empire of Friends: Soviet Power and Socialist Internationalism in Cold War Czechoslovakia. Ithaca: Cornell University Press.

Balibar, E. 2005. Difference, Otherness, Exclusion. Parallax 11, 1: 19-34.

Bayly, S. 2007. Asian Voices in a Post-Colonial Age: Vietnam, India and Beyond. Cambridge: Cambridge University Press.

Beer, B. 1998. Freundschaft als Thema der Ethnologie. Zeitschrift für Ethnologie 123, 2: 191-213.

Bell, S. and S. Coleman, eds., 1999. The Anthropology of Friendship. Oxford: Berg.

Berenskoetter, F. 2007. Friends, there Are no Friends? An Intimate Reframing of the International. Millennium - Journal of International Studies 35, 3: 647-76.

Björkdahl, A., M. Hall, and T. Svensson. 2019. Everyday International Relations: Editors' Introduction. Cooperation and Conflict 54, 2: 123-30.

Bork-Hüffer, T. and Y. Yuan-Ihle. 2014. The Management of Foreigners in China: Changes to the Migration Law and Regulations during the Late Hu-Wen and Early $\mathrm{Xi}-\mathrm{Li}$ Eras and Their Potential Effects. International Journal of China Studies 5, 3: 571-98.

Brady, A.-M. 2003. Making the Foreign Serve China: Managing Foreigners in the People's Republic. Lanham: Rowman \& Littlefield.

Brandt, A. 2013. Among Friends? On the Dynamics of Maori-Pakeha Relationships in Aotearoa New Zealand. Göttingen: V\&R unipress.

Bukh, A. 2020. These Islands Are Ours: The Social Construction of Territorial Disputes in Northeast Asia. Stanford: Stanford University Press. 
Bulag, U. 2003. Mongolian Ethnicity and Linguistic Anxiety in China. American Anthropologist 105, 4: 753-63.

Bulag, U. 2010. Collaborative Nationalism: The Politics of Friendship on China's Mongolian Frontier. Lanham: Rowman \& Littlefield.

Callahan, W. 2001. China and the Globalisation of IR Theory: Discussion of 'Building International Relations Theory with Chinese Characteristics.' Journal of Contemporary China 10, 26: 75-88.

Carsten, J., ed. 2000. Cultures of Relatedness: New Approaches to the Study of Kinship. Cambridge: Cambridge University Press.

Chang, J. 2013. Affect, Trust and Friendship: A Case Study of Chinese and Zambian Relationships at the Workplace. International Journal of Business Anthropology 4, 1: 38-61.

Dai, J. 2018. After the Post-Cold War: The Future of Chinese History. Lisa Rofel, ed. Durham: Duke University Press.

Derrida, J. 2005. Politics of Friendship. London: Verso.

Desai, A. and E. Killick, eds. 2013. The Ways of Friendship: Anthropological Perspectives. Oxford: Berghahn.

Descharmes, B., E. Heuser, C. Kruger, and T. Loy, eds. 2011. Varieties of Friendship: Interdisciplinary Perspectives on Social Relationships. Göttingen: V\&R unipress.

Emerson, R. 1993[1841]. Self-Reliance, and other Essays. New York: Dover.

Fortes, M., 1953. The Structure of Unilineal Descent Groups. American Anthropologist 55, 1: 17-41.

Freeman, C. 2011. Making and Faking Kinship: Marriage and Labor Migration between China and South Korea. Ithaca: Cornell University Press.

Friedman, J. 2015. Shadow Cold War: The Sino-Soviet Competition for the Third World. Chapel Hill: University of North Carolina Press.

Geertz, C. 1978. The Bazaar Economy: Information and Search in Peasant Marketing. American Economic Review 68, 2: 28-32.

Grayling, A. 2013. Friendship. London: Yale University Press.

Gregory, C. 1982. Gifts and Commodities, London: Academic Press.

Gudykunst, W. 1985. An Exploratory Comparison of Close Intracultural and Intercultural Friendships. Communication Quarterly 33, 4: 270-83.

Hirsch, F. 2005. Empire of Nations: Ethnographic Knowledge and the Making of the Soviet Union. Ithaca: Cornell University Press.

Hopf, T. 2002. Social Construction of International Politics: Identities \& Foreign Policies, Moscow, 1955 \& 1999. Ithaca: Cornell University Press.

Hruschka, D. 2010. Friendship: Development, Ecology, and Evolution of a Relationship. Berkeley: University of California Press.

Huang, Y. 2008. Conceptualizations of Friendship between Chinese International Students and U.S. Nationals. PhD diss., Texas Tech University.

Humphrey, C. 2004. Cosmopolitanism and Kosmopolitizm in the Political Life of Soviet Citizens. Focaal-European Journal of Anthropology 44: 138-52.

Inda, J. and R. Rosaldo. 2008. The Anthropology of Globalization: A Reader. Hoboken: Wiley-Blackwell.

Jersild, Austin. 2014. The Sino-Soviet Alliance: An International History. Chapel Hill: University of North Carolina Press.

Kalugin, D. 2009. Istoriia Poniatiia 'druzhba'-Ot Drevnei Rusi Do XVIII Veka. In Druzhba: Ocherki Po Teorii Praktik. Sbornik Statei. St. Petersburg: Evropeiskii universitet, 187-289.

Kaple, D. 1994. Dream of a Red Factory: The Legacy of High Stalinism in China. Oxford: Oxford University Press. 
Kharkhordin, O. and A. Kovaleva. 2009. Gradatsii blizosti v sovremennoi rossiiskoi druzhbe. In O. Kharkhordin, ed., Druzhba: ocherki po teorii praktik. Sbornik statei. St. Petersburg: Evropeiskii universitet, 48-77.

Kipnis, A. 1997. Producing Guanxi: Sentiment, Self, and Subculture in a North China Village. Durham: Duke University Press.

Kon, I. 1987. Druzhba: Etiko-psikhologicheskii ocherk. Moscow: Politizdat.

Kornai, J. 1992. The Socialist System: The Political Economy of Communism. Oxford: Clarendon.

Koschut, S. and A. Oelsner. 2014. Friendship and International Relations. London: Palgrave.

Kriz, A. and B. Keating. 2010. Business Relationships in China: Lessons about Deep Trust. Asia Pacific Business Review 16, 3: 299-318.

Kruglova, A. 2017. Social Theory and Everyday Marxists: Russian Perspectives on Epistemology and Ethics. Comparative Studies in Society and History 59, 4: 759-85.

Kutcher, N., 2000. The Fifth Relationship: Dangerous Friendships in the Confucian Context. American Historical Review 105, 5: 1615-29.

Laidlaw, James. 2000. A Free Gift Makes no Friends. Journal of the Royal Anthropological Institute 6, 4: 617-34.

Lan, S. 2019. Reconstructing Blackness in Grassroots Interactions between Chinese and Africans in Guangzhou. Anthropological Quarterly 92, 2: 481-508.

Larin, V. 1995. 'Yellow Peril' Again? The Chinese and the Russian Far East. In S. Kotkin and D. Wolff, eds., Rediscovering Russia in Asia: Siberia and the Russian Far East. Armonk: M. E. Sharpe, 290-301.

Ledeneva, A. 2006. How Russia Really Works: The Informal Practices that Shaped Post-Soviet Politics and Business. Ithaca: Cornell University Press.

Ledeneva, A. 2008. Blat and Guanxi: Informal Practices in Russia and China. Comparative Studies in Society and History 50, 1: 118-44.

Li, Y. 2018. China's Soviet Dream: Propaganda, Culture, and Popular Imagination. London: Routledge.

Liu, L. 1995. Translingual Practice: Literature, National Culture, and Translated Modernity-China, 1900-1937. Stanford: Stanford University Press.

Liu, Y. and F. Dervin. 2020. Racial Marker, Transnational Capital, and the Occidental Other: White Americans' Experiences of Whiteness on the Chinese Mainland. Journal of Ethnic and Migration Studies, 14 May: 1-18.

Lourié [Lur'e], S. 2011. "Druzhba narodov" v SSSR: natsional'nyi proekt ili primer spontannoi mezhetnicheskoi samoorganizatsii? Obshchestvennye nauki $i$ sovremennost' 4: 145-56.

Marcus, G. 1995. Ethnography in/of the World System: The Emergence of Multi-Sited Ethnography. Annual Review of Anthropology 24: 95-117.

Martin, T. 2001. The Affirmative Action Empire: Nations and Nationalism in the Soviet Union, 1923-1939. Ithaca: Cornell University Press.

Martínez, I. 2014. The Paradox of Friendship: Loyalty and Betrayal on the Sonoran Frontier. Journal of the Southwest 56, 2: 319-44.

McGuire, E. 2017. Red at Heart: How Chinese Communists Fell in Love with the Russian Revolution. Oxford: Oxford University Press.

Nordin, A. and G. Smith. 2018. Reintroducing Friendship to International Relations: Relational Ontologies from China to the West. International Relations of the AsiaPacific 18, 3: 369-96.

Pahl, Ray. 2000. On Friendship. Hoboken: Wiley.

Pasternak, B., 1969. The Role of the Frontier in Chinese Lineage Development. Journal of Asian Studies 28, 3: 551-61. 
Reeves, M. 2014. Border Work: Spatial Lives of the State in Rural Central Asia. Ithaca: Cornell University Press.

Reina, R. 1959. Two Patterns of Friendship in a Guatemalan Community. American Anthropologist 61, 1: 44-50.

Roshchin, E. 2009a. Poniatie 'druzhba' v Kontekste Mezhdunarodnykh Otnoshenii. In Druzhba: Ocherki Po Teorii Praktik. Sbornik Statei. St. Petersburg: Evropeiskii universitet v Sankt-Peterburge, 290-423.

Roshchin, E. 2009b. Supplanting Love, Accepting Friendship: A History of Russian Diplomatic Concepts. Rediscriptions 13: 125-46.

Scott, J. 1998. Seeing Like a State: How Certain Schemes to Improve the Human Condition Have Failed. New Haven: Yale University Press.

Shlapentokh, V. 1984. Love, Marriage, and Friendship in the Soviet Union: Ideals and Practices. Santa Barbara: Praeger.

Simpson, A. 2014. Mohawk Interruptus: Political Life across the Borders of Settler States. Chapel Hill: Duke University Press.

Skocpol, T. 1979. States and Social Revolutions: A Comparative Analysis of France, Russia and China. Cambridge: Cambridge University Press.

Slezkine, Y. 1994. The USSR as a Communal Apartment, or How a Socialist State Promoted Ethnic Particularism. Slavic Review 53, 2: 414-52.

Smart, A. 1999. Expressions of Interest: Friendship and Guanxi in Chinese Societies. In S. Bell and S. Coleman, eds., The Anthropology of Friendship. Oxford: Berg, 119-36.

Ssorin-Chaikov, N. 2003. The Social Life of the State in Subarctic Siberia. Stanford: Stanford University Press.

Stafford, C. 2000. Chinese Patriliny and the Cycles of Yang and Laiwang. In J. Carsten, ed., Cultures of Relatedness: New Approaches to the Study of Kinship. Cambridge: Cambridge University Press, 35-54.

Stasch, R. 2009. Society of Others: Kinship and Mourning in a West Papuan Place. Berkeley: University of California Press.

Stern, D. 2015. 'Nado Minimum!' Mediating Respectability at Informal Markets on the Russian-Chinese Border. Inner Asia 17: 5-30.

Strickland, M. 2010. Aid and Affect in the Friendships of Young Chinese Men. Journal of the Royal Anthropological Institute 16, 1: 102-18.

Sukhotin, I. and L. Vidgop. 1958. Druzhba Velikaia i Trogatel'naia. Moscow: Molodaia gvardia.

Theys, S. 2017. Constructivism. In S. McGlinchey, R. Walters, and C. Scheinpflug, eds., International Relations Theory. Bristol: E-International Relations, 36-41.

Tsing, A. 2005. Friction: An Ethnography of Global Connection. Princeton: Princeton University Press.

Urbansky, S. 2012. A Very Orderly Friendship: The Sino-Soviet Border under the Alliance Regime, 1950-1960. Eurasia Border Review 3: 35-52.

Vincent, C., S. Neal, and H. Iqbal. 2018. Friendship and Diversity: Class, Ethnicity and Social Relationships in the City. London: Palgrave Macmillan.

Walker, Harry. 2013. State of Play: The Political Ontology of Sport in Amazonian Peru. American Ethnologist 40, 2: 382-98.

Wehrer, M. 2019. Anthropology and International Relations. Oxford Research Encyclopedia of International Studies, May. Online at: https://oxfordre.com/ internationalstudies/view/10.1093/acrefore/9780190846626.001.0001/acrefore9780190846626-e-530 (accessed 5 Apr. 2021).

Weitegepu 维特戈普, Suhuojing 苏霍京, and Li Hongdun 李鸿敦, trans. 1983. Weida er dongren de youyi. Nanning: Guangxi renmin chubanshe. 
Wolf, E. 1966. Kinship, Friendship, and Patron-Client Relations in Complex Societies. In M. Banton, ed., The Social Anthropology of Complex Societies. London: Tavistock, $1-22$

Xiang, Biao. 2013. Multi-Scalar Ethnography: An Approach for Critical Engagement with Migration and Social Change. Ethnography 14, 3: 282-99.

Yan, Yunxiang. 2003. Private Life under Socialism: Love, Intimacy, and Family Change in a Chinese Village, 1949-1999. Stanford: Stanford University Press.

Yan, Yunxiang. 2009. The Individualization of Chinese Society. London: Berg.

Yang, M. 1994. Gifts, Favors, and Banquets: The Art of Social Relationships in China. Ithaca: Cornell University Press.

Yang Shi 杨适. 1993. 'Youyi' (Friendship) guannian de ZhongXi chayi. Beijing Daxue Xuebao (Zhexue Xuehuikexue Ban) 1: 31-38.

Young, B. 2019. Cultural Diplomacy with North Korean Characteristics: Pyongyang's Exportation of the Mass Games to the Third World, 1972-1996. International History Review 42, 3: 543-55.

Yurchak, A. 2006. Everything Was Forever, Until It Was no More: The Last Soviet Generation. Princeton: Princeton University Press.

Zang, X. 2003. Ethnicity and Urban Life in China. London: Routledge.

Zhan, M. 2009. Other-Worldly: Making Chinese Medicine through Transnational Frames. Durham: Duke University Press.

\begin{abstract}
Relations between states are usually framed in human terms, from partners to rivals, enemies or allies, polities and persons appear to engage in cognate relationships. Yet whether or not official ties and relationships among people from those states actually correspond remains less clear. "Friendship," a term first applied to states in eighteenth-century Europe and mobilized in the (post)socialist world since the 1930s, articulates with particular clarity both the promise and the limitations of harmonized personal and state ties. Understandings of friendship vary interculturally, and invocations of state-state friendship may be accompanied by a distinct lack of amity among populations. Such is the case between China and Russia today, and this situation therefore raises wider questions over how we should understand interstate and interpersonal relationships together. Existing social scientific work has generally failed to locate either the everyday in the international or the international in the everyday. Focusing on both Chinese and Russian approaches to daily interactions in a border town and the official Sino-Russian Friendship, I thus suggest a new scalar approach. Applying this to the Sino-Russian case in turn reveals how specific contours of "difference" form a pivot around which relationships at both scales operate. This study thus offers both comparison between Chinese and Russian friendships, and a lens for wider comparative work in a global era of shifting geopolitics and cross-border encounters.
\end{abstract}

Key words: friendship, scales, difference, frontier, socialism, postsocialism, China, Russia 